\title{
Eliciting neutralizing antibodies with gp120 outer domain
}

\author{
Y Qin ${ }^{1 *}$, DP Han ${ }^{1}$, K Takamoto², MW Cho ${ }^{1}$ \\ From AIDS Vaccine 2012 \\ Boston, MA, USA. 9-12 September 2012
}

\section{Background}

Although gp120 elicits strong antibody responses, it fails to induce broadly neutralizing antibodies (bnAbs). One strategy being evaluated is using immunogens based on gp120 outer domain (gp120-OD). A number of gp120OD constructs have been reported. However, none of them have been shown to induce potent nAbs. Here, we describe gp120-OD-based immunogens that can induce potent nAbs.

\section{Methods}

We constructed gp120, gp120-OD, and a trimeric form of gp120-OD (ODx3) based on an M group consensus sequence. Proteins were expressed in 293 cells, and their antigenic properties were evaluated by immunoprecipitation using gp120 bnAbs (b12, 2G12 and 447-52D) and by surface plasmon resonance (SPR). Rabbits were immunized and antibody responses were characterized by ELISA and neutralization assays.

\section{Results}

All three proteins were recognized by bnAbs b12, 2 G12 and 447-52D. SPR analyses indicated that b12 has lower affinity to gp120-OD compared to gp120 or ODx3, largely due to a faster dissociation rate. All immunogens induced potent nAbs against Tier 1 viruses from clades $B, C$ and $A E$. Neutralizing activity against Tier 2 viruses was weaker and sporadic. The induction kinetic of nAbs by gp120-OD was slower than that for gp120 and ODx3. Although the V3 loop was a major target of nAbs, results suggested other epitopes are also targeted. A panel of about 100 rabbit mAbs was generated, two of which exhibited neutralizing activity. One of them was molecularly cloned and sequenced. It exhibited a

${ }^{1}$ lowa State University, Ames, IA, USA

Full list of author information is available at the end of the article similar neutralization profile as the immune serum. Work is in progress to identify its epitope.

\section{Conclusion}

We have successfully generated OD-based immunogens that can induce nAbs. Although they were effective primarily against Tier 1 viruses, the breadth of neutralizing activity achieved is highly significant. Our trimeric ODx3 construct is novel and is a highly promising immunogen for further development of OD-based immunogen.

\section{Author details}

'lowa State University, Ames, IA, USA. ${ }^{2}$ Albert Einstein College of Medicine, New York, NY, USA.

Published: 13 September 2012

doi:10.1186/1742-4690-9-S2-011

Cite this article as: Qin et al:: Eliciting neutralizing antibodies with gp120 outer domain. Retrovirology 2012 9(Suppl 2):O11.

Submit your next manuscript to BioMed Central and take full advantage of:

- Convenient online submission

- Thorough peer review

- No space constraints or color figure charges

- Immediate publication on acceptance

- Inclusion in PubMed, CAS, Scopus and Google Scholar

- Research which is freely available for redistribution 